\title{
THE RELATIONSHIP \\ BETWEEN CHRISTIANITY AND SCIENCE: \\ A BRIEF HISTORICAL STUDY \\ ON DARWINISM AND THE DUTCH \\ NEO-CALVINIST THEOLOGIANS
}

\author{
David Tong \\ International Reformed Evangelical Seminary
}

\begin{abstract}
ABSTRAK: Kesimpulan filsuf Ilse N. Bulhof bahwa Darwinisme diterima dengan mudah di Belanda dengan perlawanan datang hanya dari kalangan agama perlu diperjelas lebih lanjut. Nyatanya, perlawanan terhadap Darwinisme juga datang dari golongan akademik dan tidak semua kalangan agama menolak Darwinisme. Tanpa keberatan kaum liberal modernis menerima Darwinisme. Dua tokoh penting dari gerakan neo-Calvinisme di Belanda, Abraham Kuyper dan Herman Bavinck, juga menerima evolusi sebagai suatu fakta walaupun mereka menolak paham Darwinisme. Kesimpulan Bulhof di atas tidak seharunya dimengerti sebagai pertentangan antara iman dan ilmu. Perlawanan yang sesungguhnya bukan perlawanan antara iman dan ilmu, tapi antara dua macam worldviews yang saling bertolak belakang. Inilah yang menyebabkan tidak semua ilmuwan juga menerima Darwinisme. Menarik untuk diamati bahwa generasi kedua dari gerakan neo-Calvinisme di Belanda (misalnya, Valentine Hepp) menolak semua bentuk evolusi. Beberapa alasan
\end{abstract}


yang mencoba untuk menjelaskan diskontinuitas antara kedua generasi neo-Calvinisme ini juga akan diberikan di dalam tulisan ini.

KATA KUNCI: Abraham Kuyper, Herman Bavinck, Valentine Hepp, NeoCalvinisme Belanda, evolusi, Darwinisme, teistik evousi, penciptaan yang ber-evolusi.

ABSTRACT: The philosopher Ilse N. Bulhof's conclusion that the reception of Darwinism in the Netherlands was easy with opposition coming only from the religious quarters needs to be explained further. The fact is, opposition towards Darwinism came also from the academics and not all religious groups opposed it. The modern liberal accepted Darwinism without much reservation. Two great figures of the Dutch neo-Calvinisme, Abraham Kuyper and Herman Bavinck, accepted evolution as a fact while rejecting Darwinism. Bulfhof's conclusion above should not be understood as a conflict between faith and science. The real conflict is not between faith and science, but between two diametrically opposing worldviews. This is the reason why not all scientists embraced Darwinism. It is interesting to observe that the second generation of the Dutch neoCalvinsm (Valentine Hepp, for example) resisted all forms of evolution theories. Several possible reasons explaining the discontinuity between these two generations of neo-Calvinism will also be given in this paper. 
KEYWORDS: Abraham Kuyper, Herman Bavinck, Valentine Hepp, Dutch neo-Calvinism, evolution, Darwinism, theistic evolution, evolutionistic creation.

\section{Introduksi}

It did not take long for Darwin's Origin of Species to gain wide acceptance in the Netherlands that the philosopher Ilse N. Bulhof infers that "Darwin's progress in the Netherlands was easy," with opposition coming "only from religious quarters." ${ }^{1}$ I will attempt to clarify Bulhof's assessment here further. First, I shall argue that far from being a struggle between faith and science (e.g., theologians vs. scientists), one's reception of Darwinism was primarily determined by one's philosophical or religious alignment, i.e. one's belief or worldview. Second, Bulhof's conclusion does not warrant the view that faith was being hostile towards science. As I will show in this paper, the first generation Dutch neo-Calvinists, Abraham Kuyper and Herman Bavinck in particular, were quite receptive towards the idea of species mutation over immense geological period.

For the most part, the nineteenth century Netherlands was predominantly an agricultural society. ${ }^{2}$ And most nineteenth century Dutch people were "religious folks." For these reasons, I shall limit my study on two of the more important people groups in the

1 Ilse N. Bulhof, "The Netherlands," in The Comparative Reception of Darwinism, ed. Thomas F. Glick (Chicago and London: The University Press of Chicago, 1988), 305.

2 Ibid., 270. 
nineteenth century Netherlands, the natural scientists and the theologians.

Undoubtedly, philosophical worldview played a very important role in the formation of one's presupposition. Thus, we shall now turn to a brief discussion over some schools of philosophical thoughts that shaped the nineteenth century Netherlands.

\section{Philosophical Developments in the Nineteenth Century Netherlands}

To some extent, the nineteenth century Europe was a battle ground for few schools of thoughts. In the first place we have positivism. As a philosophical trend, the positivism of Auguste Comte is the culmination of empiricism that debuted with Francis Bacon, John Locke, and jurn Hume. ${ }^{3}$ The positivists would come to agree with Kant in asserting that reasons operate on sensations and, thus, the only kind of knowledge possible is knowledge based on senses and experiences, knowledge of the phenomenal reality. Where they differed from Kant was over the need to postulate the noumenal reality; since "concepts without percepts are empty," it was meaningless to talk about knowledge of the noumenal reality. "Metaphysics, theology, the intellectual disciple in general, even psychology according to Comte, are not sciences in the real sense of

3 Herman Bavinck, Reformed Dogmatics, ed. John Bolt, tr. John Vriend, (Grand Rapids: Baker Academic, 2003), 1:219. 
the word. Scientific knowledge is limited to the exact sciences." 4 Positivism gained its stronghold and legitimacy with the rise of natural sciences in the eighteenth and nineteenth century Europe and prepared the ground for the acceptance of mechanistic and naturalistic Darwinism. ${ }^{5}$

Another major philosophy was Hegel's Absolute Idealism. Georg Wilhelm Friedrich Hegel developed his philosophy to account for the relation between mind and nature. The "Absolute Mind," according to Hegel, shapes and moves history in a dialectical fashion: a movement directed by tensions between thesis and antithesis yielding to synthesis (a new thesis). In this dialectical philosophy of Hegel, history becomes a constant process of becoming.

Feuerbach's materialism was also important. As a materialist, Ludwig Feuerbach believed that physical matter was the only thing that exists. In addition, Feuerbach believed that abstract concepts did not actually exist. In their yearnings for religion, human beings "create God in their own image as a projection of their ideals" and "as the mirror of their hopes." But in reality, "no actual, concrete, ideal human by any name-much less a deity-exists in human image. Only concrete particular human being exists" and, thus,

4 Ibid., 1:219.

5 For the most part, in its attempt to make Christianity relevant to the modern culture, the modern (liberal) theologians embraced positivism by "the abolition of the supernatural." George Harinck, "Twin Sisters with a Changing Character: How Neo-Calvinists Dealt with the Modern Discrepancy between Bible and Natural Science," in Nature and Scripture in the Abrahamic Religions: 1700 - Present, ed. Jitse M. van der Meer and Scott Manderlbrote,Brill's Series in Church History 37, ed. WimJanse (Leiden and Boston: Brill, 2008), 2:325. 
humankind is "the proper object of worship." One of Feuerbach agenda was to translate Christianity without a reference to anything transcendence. To this end, Feuerbach believed that "he could rid the world of idolatry by translating the historic Christian confession into a language without any theological overtones," a task that he carried on his most influential work, The Essence of Christianity. ${ }^{6}$ With the increasing materialistic view of the universe in nineteenth century Europe, the Netherlands included,

Last, but not least, was Spinoza's monism. Baruch de Spinoza believed that all diversities in the world were reducible to one single reality, substance. The tension between Spinoza and Hegel was clear; the former reduces the universe into being, the later into a process of becoming.

One of the reasons that explained the attractiveness of Darwinism to philosophers was its ability to reconcile some of these conflicting philosophical developments: e.g., Spinoza's philosophy of being vs. Hegel's philosophy of becoming and Feuerbach's materialism vs. Hegel's philosophy of becoming. On the latter, Bavinck writes:

"Hegel's pantheism has furnished the idea of the absolute, eternal process of becoming. The materialism of Feuerbach has applied this idea to the world of matter and force as the only existing one. And in the struggle for existence, in the

\footnotetext{
6 Richard Lints, "The Age of Intellectual Iconoclasm: The Nineteenth Century Revolt against Theism," in Revolutions in Worldview: Understanding the Flow of Western Thought (Phillipsburg: P\&R, 2007), 289-291.
} 
natural and sexual choice of propagation, in the inheritance of the acquired properties, and in the accommodation to surroundings, Darwin's theory of development has provided the necessary means to make this process of the eternal becoming intelligible in the material world. Thus with the change of the century there has been gradually a new worldview arisen which undertakes to interpret not merely the inanimate but also the animate creations, not merely the unconscious abut also the conscious, and all this without exception independently of God, and only and alone from an immanent self-development."7

\section{The Reception of Darwinism in the Netherlands: Among the Natural Scientists}

Bulhof observes that Darwin's theories were "well received by the academic community." 8 Anticipation for an evolutionary mechanism already existed in the Netherlands' academic community before 1859 and it helped advancing Darwinism after 1859. Dutch natural scientists, prior to 1859 , were already puzzled by the new paleontological and geological data, and "many felt that these facts pointed somehow in the direction of a gradual development of the earth and of the plant and animal species." ${ }^{9}$ Two natural scientists can be mentioned: Pieter Harting (1812 - 1885) and Franciscus Cornelis Donders (1818 - 1889).

In his paper "A comparison between the prehistoric and

\footnotetext{
7 Herman Bavinck, “Creation or Development," trans. Rev. J. Hendrik de Vries, The Methodist Review 83(November 1901): 850.

8 Bulhof, "The Netherlands," 284.

9 Ibid.
} 
contemporary creations," published in 1857, Harting pointed out that what we observe in the world is change and that change takes time. The world as we know it today, explained Harting, "has a past of millions of years, during which many species that are now extinct lived." By 1858, Harting was already convinced that evolutionary theory would become the future of science. ${ }^{10}$

But perhaps more importantly was the work of Donders. In 1848 Donders, a young professor of physiology, delivered his inaugural address to the faculty and students of the University of Utrecht with a topic titled "The harmony of animal life: the manifestation of laws." In this address Donders posited that everything is part of the great natural organism and pointed to the order and harmony in nature which exhibits most strikingly in the interdependence of the animal world and vegetation. From this order and harmony scientists move to discover the laws governing the development of this harmony. Donders attempted to give a purely mechanistic explanation to the harmony in living nature by postulating three laws governing transformation in animal organism: that animal organism is transformed by the conditions it finds itself in; that this transformation will affect every organ, every part of the body, as the circumstances demands from it; and that this transformation will be inherited to the organism's posterity.

As pointed out by Bulhof, however, Donders' mechanistic explanation "is not yet Darwinism" for it lacks "the perspective of

$10 \quad$ Ibid.,277. 
geological time and a sense of history in which the species were shaped during a long process."11 Nevertheless, the fact that this was done prior to Darwin's publication of Origin of Species underscores the importance of Donders' works. Darwin himself later acknowledged that Donders "closely anticipated the concept of natural selection." ${ }^{12}$ While the origin of Donders' laws may be speculated, one thing is certain: Donders' mechanistic explanation of the harmony of nature would make him receptive to Darwin's own explanation for the origin of species. ${ }^{13}$

In Bulhof's estimation, together “Donders's and Harting's treatises provided a fertile soil for the reception of Darwin's theories."14Donders worked out a naturalistic mechanism for species development and Harting, while not very much concerned with explaining the mechanism that governs the evolutionary process, nevertheless "was aware of the immense time perspective that the development of species involves."15

Having said this, few clarifications need to be made to explain Bulhof's observations. The acceptance of Darwinism by the academic community was not homogenous. As Bulhof has observed himself, there are some scientists who, while accepting theory of evolution in general, opposed Darwinism. This is especially true towards the end

\footnotetext{
11 Ibid., 274.

12 Ibid.,272.

13 Ibid.,274.

14 Ibid.

15 Ibid., 278.
} 
of the nineteenth century and well into the first decades of the twentieth century, a period when Darwinism was eclipsed by the rise of other evolutionary theories, such as Lamarckism, the mutation theory, and theistic evolutionary theory. The physician Rijk Kramer (1870 - 1942), for example, regarded that species change was a wellestablished fact and considered Hugo de Vries' (1848 - 1935) mutation theory as a satisfactory explanation for the mechanism behind the evolution of the species. Kramer, like many of his contemporary scientists, was convinced that Darwin's theory of natural selection had been repudiated. He further embraced a non-mechanistic explanation of the origin of species, arguing that no mutation was random and that there was purpose and goal-directed vital force, attributed to God, responsible for these mutations. ${ }^{16}$

More importantly, the scientists' own belief, their philosophical or religious orientations - a factor not taken into account by Bulhofmust be evaluated. This factor is of particular importance because the scientists themselves did not approach the question of evolution from a neutral stand point. In fact, in Abraham Kuyper's assessment, the conflict over Darwinism was a conflict over beliefs. If the scientists were philosophically aligned with positivism, for example, then it is hardly surprising that they would be quite receptive to Darwinism. In that case, Darwinism would be seen as the only tenable explanation for the developments observed. Indeed, the two most important

16 Rob P.W. Visser, "Dutch Calvinists and Darwinism, 1900-1960" in Nature and Scripture in the Abrahamic Religions: 1700 - Present, ed. Jitse M. van der Meer and Scott Manderlbrote, Brill's Series in Church History 37, ed. WimJanse (Leiden and Boston: Brill, 2008), 2:300. 
scientists discussed by Bulhof, Harting and Donders, might have had such positivistic inclination. As Bulhof himself points out, “Significantly enough, Modernism's main spokesman was a colleague and close friend of the Darwinists Harting and Donders: Cornelis Willem Opzoomer ... who since 1846 had been professor of philosophy at the University of Utrecht." ${ }^{17}$ Opzoomer was known to embrace both positivism and monism.

This last point is supported by the fact that the scientists' age seemed to play an important factor in determining their reception, or rejection, of Darwinism. Bulhof points out that in the sixties, within few years of the publication of Darwin's Origin of Species, "most professors in natural history were Darwinist: in Utrecht, Harting (zoology) and Donders (physiology); in Leiden, Selenka (zoology); in Groningen, H. C. van Hall (botany and zoology); in Amsterdam, T. C. Place (physiology) and C. A. J. A. Oudemans (botany); in the Institute of Technology at Delft, W. C. H. Staring, 'the father of Dutch geology' (geology and mineralogy); and, at the Harlem Teylers Institute, the natural historian T. C. Winkler."18 Especially among the younger scientists, "the Darwinian theory of an evolution of the species quickly changed in status from a daring hypothesis to an undisputed fact." 19 Exposed since their young age to the many different philosophical thoughts (discussed above) and to the theology of the modernist

\footnotetext{
17 Bulhof, "The Netherlands," 285.

18 Ibid., 278.

19 Ibid.,284.
} 
liberals (discussed below), these younger scientists, without doubt, would be more receptive towards Darwinism. The two scientists who rejected Darwin's theory of natural selection, van der Hoeven and Vrolik, "were both at the end of their careers and about to be replaced by a younger generation of scientists." ${ }^{20}$ The views of both van der Hoeven and Vrolik would have been matured at the time Darwin's Origin of Species came on the scene.

Things were different among the more orthodox oriented scientists. The Christian Association for Scientists and Physicians, founded in 1896, for example, had a strong Calvinistic character and its members testified, again and again, that "a true understanding of nature could only be reached if scientists accepted the guidance of a Christian worldview.... The association's ideal was to contribute to the production of scientific knowledge on the basis of the 'Calvinists confession of faith.'"21 We shall discuss two of its members.

Leendert Bouman (1869 - 1936), physician and the chief editor of the association's journal for many years, severely criticized any type of evolution. Holding strongly to God's revelation, Bouman "considered it a matter of fact that man and animals had been created separately and that it was absolutely impossible for one species to be transformed into another." He felt it ridiculous to formulate a theory to explain a process that did not exist and concluded that "Darwin

\footnotetext{
20 Ibid., 284.

21 Visser, "Dutch Calvinists and Darwinism," 299.
} 
was nothing but a fraud." 22 The resistance to Darwinism went even into the first decades of the twentieth century; the rejection of Darwinism "met with little opposition in the association or indeed elsewhere among Dutch Calvinists." 23 Bouman and his many sympathizers based themselves explicitly on the "eternal truths of God's Word." They saw only one course of action when dealing with Darwin's theory, which was to combat it relentlessly, and they considered this their primary task. ${ }^{24}$

Frederik Buytendijk (1887 - 1974), physiologist and professor in the medical department of the Free University, provided another example. In May of 1920 Buytendijk gave a lecture at the annual meeting of the Christian Association of Scientists and Physicians on "Evolutionary Theories." While admitting that the theory of Lamarck and Darwin displayed some inadequacies, Buytendijk still argued for the evolutionary origin of species interpreted as a preordained process. Inspired by the German embryologist Hans Driesch (1867 1941) and by the French philosopher Henri Bergson (1859 - 1941), Buytendijk suggested that "evolution was God's way to create plants and animals." 25 In short, by the early decades of the twentieth

\footnotetext{
22 Ibid.,299.

23 Emphasize is mine. Ibid.,115.

24 Visser, "Dutch Calvinists and Darwinism," 299.

25 Of particular interest was Buytendijk's view on human evolution. While making himself clear that he did not have any doubt concerning man's mental endowments as brought forth by special creation, "he did not rule out that, as physical entity, man might have descended from some kind of higher ape." Until Buytendijk's lecture in 1920, no Dutch Calvinist had expressed the dualistic origin of human evolution. Buytendijk's view, as can be expected, "received a rather negative reception by the members of the association." Visser, "Dutch Calvinists and
} 
century, as late as the 1920s, theistic evolutionary theory was a viable alternative for the Dutch Calvinist natural scientists.

In summary, the opposition of Darwinism did not come from the religious quarters only but also from the academic community as well. The existence of other evolutionary theories play important factors in determining one's reception, or rejection, of Darwinism. But more importantly, the scientists' own beliefs exerted the strongest pressure. This is clear when one considers that by 1930s, "the total number of scientists among Dutch Calvinists who accepted some theory of evolution [not exclusively that of Darwinism] did not exceed a dozen." And because it was considered incompatible with their own beliefs, "the great majority of Calvinists scientists resolutely condemned Darwin's theory of evolution." ${ }^{26}$

\section{The Reception of Darwinism in the Netherlands: Among the Theologians}

For the most part, reception of Darwinism among the theologians was also determined by the theologians' own beliefs just like the other group already surveyed. To this extend, Bulhof's

\footnotetext{
Darwinism," 300-301. At this point, it is worth nothing that at roughly the same time, Warfield, in his 1915 article "Calvin's Doctrine of Creation," also argued for the dualistic origin of human. Warfield: "It should scarcely be passed without remark that Calvin's doctrine of creation is, if we have understood it aright, for all except the souls of men, an evolutionary one. The 'indigested mass,' including the 'promise and potency' of all that was yet to be, was called into being by the simple fiat of God. But all that has come into being since-except the soul of men alone-has arisen as a modification of this original world-stuff by means of the interaction of its intrinsic forces." Benjamin B. Warfield, "Calvin's Doctrine of Creation," in Noll, The Princeton Theology, 297.

26 Quotations from Visser, "Dutch Calvinists and Darwinism," 304.
} 
conclusion that "Darwin's progress in the Netherlands was easy" with opposition coming "only from religious quarters" 27 deserves further clarification. To begin with, not all religious groups of the nineteenth century Netherlands opposed Darwinism. There were three major religious groups in the Netherlands: the modernist liberals (the leading group), or simply "the modernists," 28 the Roman Catholics, and the orthodox Protestants (predominately Calvinists). Due to the sheer number of Protestants in the Netherlands-after all, "the Netherlands emerged . . . as a Protestant nation after its revolt against Spain in the sixteenth century, and ever since its intellectual and moral climate has been permeated with Calvinism" 29 - criticism from Roman Catholics did not pose any serious challenge. ${ }^{30}$ Thus, we are left with two religious groups to consider, the modernists and the orthodox Protestants.

Theology was an important subject at Dutch universities. Traditionally, ministers of the Dutch Reformed Church (Nederlandse Hervormde Kerk), the State Church until the new Dutch Constitution of 1848 established the separation of Church and State, were educated at

\footnotetext{
27 Bulhof, "The Netherlands," 305.

28 Or, simply, "the modernists." This label accurately describes the liberal theologians because it shows their commitment to the modernity of the nineteenth century rather than to their own Protestant principle.

29 Bulhof, "The Netherlands," 301-302.

30 The historian of the Netherlands' Catholicism, L. K. Rogier, a Catholic himself, characterized the criticisms from Roman Catholic circles in the nineteenth century as an "instinctive rejection by people who do not know the facts." For brief discussion of Darwin's reception (rejection, to be precise) among the Roman Catholic circles, see Bulhof, "The Netherlands," 301.
} 
the major Protestant universities of Groningen, Leiden, and Utrecht. Even until the 1870s, theology "constituted the second largest faculty among the Dutch universities, with twenty to thirty-five percent of the student population." 31 Without doubt, the rise of modernism, with its positivistic character, exerted a great influence among the Dutch Reformed Church. Changes in the Dutch theological landscape were inevitable. Faced with developments in philosophical thoughts (in particular, positivism, Spinoza's monism, Hegelian philosophy of becoming, and Feuerbach's materialism) and increasing naturalism in the fields of science (Darwinism, in particular) in a culture where the natural sciences were held in a high esteem, the modern theologians were convinced that the only way for them to preserve the relevance of the church for society is by distancing themselves from Calvin and the Synod of Dort. The old religion was simply untenable. Differentiation of theology started to take place in the beginning of the nineteenth century and eventually resulted in a schism within the Dutch Reformed Church in 1834.

In the academia setting, Dutch's theological differentiation began at the University of Leiden. ${ }^{32}$ Two modern theologians were of particular importance: Johannes HenricusScholten(1811 - 1885) and

31 Harinck, “Twin Sisters," 317. This number was in decline, however. As pointed out by Harinck, after 1882 "the theology faculties of the three oldest universities - Groningen, Leiden, and Utrecht, - lost their claim to sheer numerical dominance, even though they remained large throughout the nineteenth century." However, it is important to note that the reason for this relative decline "was not that interest in the study of theology decreased but that the number of students in other fields grew rapidly, particularly in the faculties of medicine and mathematics and physics." (Harick, “Twin Seisters," 317).

32 Harinck, "Twin Sisters," 319. 
Abraham Kuenen (1828 - 1891). Scholten was a philosophical monist and when he arrived in Leiden in 1843, "he was already a mature theologian" and "was not going to make any drastic changes in his thinking." ${ }^{33}$ Both of Scholten and Kuenen "manifested the new vision by abandoning belief in the supernatural and therefore rejecting the idea of divine revelation with its message of sin and salvation, but the thinker's own reasoning powers." 34

The philosopher Cornelis Willem Opzoomer, briefly mentioned already, came to Utrecht in 1846 with his monisticand positivisticphilosophy. As a monist he "replaced the doctrine of a fundamental difference between nature and the supernatural with a strict monism." ${ }^{35}$ As a positivist he considered the phenomenal reality as the only one reality, "accepted only empirical knowledge as certain and trustworthy," 36 and employed empirical method of the natural sciences to theology. ${ }^{37}$ Though a philosopher, it is important to note that Opzoomer, the main spokesman of Modernism, also exerted a great influence on Dutch society in general "because he trained Protestant ministers, and ministers at this time were still an important intellectual force in the community." 38 The importance of Opzoomer

33 Ron Gleason, Herman Bavinck: Pastor, Churchman, Statesman, and Theologian (Phillipsburg: $P \& R, 2010), 49-50$.

34 Harinck, “Twin Sisters," 320.

35 Ibid.

36 Bulhof, "The Netherlands," 285.

37 Harinck, “Twin Sisters," 320.

38 Bulhof, "The Netherlands," 285. 
upon Dutch Protestant ministers was highlighted by the fact that towards the end of Opzoomer's academic life in the 1880s, the faculty of theology in Utrecht was the largest theological faculty in the Netherlands, registering $55 \%$ of all of Netherlands theological students combined together. Things were different, however, by the turn of the century.

Despite persecutions, the Separatists movement continued to grow and increased rapidly in number. To meet the need for its ministers' training, the group founded its own seminary, orthodox and Calvinistic in character, the Theologische School in Kampen in 1854. For the next 15 years, this new school "registered an average of fifteen students per year. This meant that the seminary in Kampen soon equaled the smallest university theological faculty, that of Groningen, in size." ${ }^{39}$ In fact, within few decades, we witness the shift of the center of theological training as the result of this theological differentiation. This shift, however, was gradual and did not become prominent until the end of the nineteenth century, if not decades into the twentieth century. For the most part of the nineteenth century, the theological faculty of the Dutch universities would still be predominantly modern in character, a condition that necessitated the founding of the Theological Seminary in Kampen in 1854 to establish a "bastion of orthodoxy." 40 The quotation by George Harinck below may provide further explanation:

\footnotetext{
39 Harinck, “Twin Sisters," 318.

40 Gleason, Herman Bavinck, 22.
} 
"Change continued with the passage of a Higher Education Act in 1876 that provided for the elevation of Amsterdam's old Athenaeum to university status. This new university also included a faculty of theology. In addition, in 1880 a non-public "free university" was founded, the VrijeUniversiteit (Calvinists in character), with its own theological faculty. Within the space of thirty years the number of faculties for Protestant theology had doubled. In 1880 the one in Utrecht was the largest with 126 students, followed by Kampen (34), Leiden (24), Amsterdam (21), Groningen (16) and the Free University of Amsterdam (8). Within five years the theological faculty of this Free University had become the second largest, and in 1920 it became the largest, surpassing Utrecht. Until 1940, Utrecht, the Free University of Amsterdam and Kampen together attracted about three quarters of the Protestant theological student body." 41

Based on data given above we can conclude that the modernists dominated the theological landscape of the Netherlands until towards the end of the nineteenth century. These religious group quite willingly embrace Darwinism and did not pose any opposition towards it. And, as expected, the relationship between these modernists and the Darwinian supporters was symbiotic. The modernists found Darwinism's explanation of progress in nature to correlate well with their faith in progress, reason, and science. In addition, the progress of increasingly mechanistic natural sciences and the dogma of Darwinism evolution, in particular, fostered these modernists' commitment to positivism and monism. ${ }^{42} \mathrm{As}$ a result, the

\footnotetext{
41 Harinck, “Twin Sisters," 318.

42 Thus, as a result, it is no surprise that the modernists rejected anything supranatural in history; the natural is historical and the historical is natural. Under the influence of modern theology, the notion of Bible as a revelation of God was lost. In addition, the modernists rejected the dual-authorship, divine and human, of the Bible; the Bible was seen as a product of human writers through historical and natural processes and is, thus, subject to the modernist' historical-
} 
modernists very easily assimilated Darwinian evolutionary into their theology. In their eyes, Darwinism helped the cause for the modernists to outline their ideas and stance on society. ${ }^{43}$ In returns, the idea of progress, deeply embraced in the theological framework of these modernists, provided a fertile ground for the acceptance of Darwinism by the nineteenth century Netherland society at large. ${ }^{44}$ Only in this context can we understand Bulhof's assessment that "Darwin's progress in the Netherlands was easy"; serious opposition from the modernists were even lacking.

The picture was more complex among orthodox Protestants. There were fundamentalists who took literalist approach to the Bible and vehemently opposed Darwinism. At the turn of the nineteenth century, two figures stood up representing the new Protestantism, the Dutch neo-Calvinists, Abraham Kuyper and Herman Bavinck. Though strong Calvinists, their view towards science distanced themselves from the fundamentalists. The reactions of these two Dutch Calvinists theologians towards the pressure of modern science of their days is one worthy of study.

\section{Darwinism and the Dutch neo-Calvinists: Abraham Kuyper and Herman Bavinck}

It must be pointed out that the two most important figures in

criticism method.

43 Bulhof, "The Netherlands," 305.

44 The role of the Dutch ministers were especially potent in shaping the agricultural society of the nineteenth century Netherlands. 
Dutch neo-Calvinism, Kuyper and Bavinck, were students at Leiden under Scholten (1850s and 1870s, respectively). However, neither Kuyper nor Bavinck followed the footsteps of Scholten and his pupils. ${ }^{45}$ For them, modern theology is diametrically opposed to the dogmatic teaching of Christian supernaturalism; accepting one implies abandoning the other. The Leiden experience was particularly important for both Kuyper and Bavinck because the neo-Calvinist movement in the Netherland was, primarily, "a reaction to modern theology." ${ }^{46}$ Having studied at Leiden under liberal theologians, such as Scholten and Keunen, allowed Kuyper and Bavinck to engage the modern theologians critically and, in so doing, formulated their own distinct views of science.

The ethical theologians also attempted to counter the positivism of the modernists in a way different from Kuyper. The ethical theologians correctly pointed the problem with modernists' theology: its positivistic metaphysics. Reacting against the metaphysics of positivism, then, the ethical theologians ran towards romanticism ${ }^{47}$

\footnotetext{
45 Harinck, "Twin Sisters," 325.

46 Ibid.

47 Embracing romanticism, some theologians developed Ethical Theology as a counter measure against the modernists. Having its origin in Jean-Jacques Rousseau, Romanticism can be thought as a protest against Enlightenment and its emphasis on the primacy of reason. A Romantic philosopher would agree with Kant that there was a realm beyond the phenomena, but disagreed with Kant in his agnosticism of the noumenal reality. The final certainty of the truths of faiths (e.g., of the existence of God, of the freedom of the will, and of the immortality of the soul), "are not to be found in the theoretical but in the practical sphere, in the original and immediate witness of feeling that is deeper and much more reliable than the reasoning mind."Herman Bavinck, "Philosophy of Religion (Faith)," in Essays on Religion, Science, and Society, ed. John Bolt, tr. Harry Boonstra and G.Sheeres (Grand Rapids: Baker Academics, 2008), 27.
} 
and argued that "reliable knowledge of the Christian faith should no longer be sought in historical facts." Rather "the ultimate ground of faith had to be found in the subject." Daniel Chantepie de la Saussaye (1818 - 1874), a disciple of Schleiermacher, for example, claimed that there was no external authority in religion and objective truth only "manifests itself in the conscience and life of the Christian." Answering the historical criticism of the modernists, de la Saussaye argued that "the church should not take refuge in any outward authority, like the confession or Scripture," because the truth of the Christian religion "is confirmed in human conscience by the witness of the Holy Spirit," and for that reason, "cannot be disturbed by any historical criticism." 48 At the end, the ethical theologians grounded the reality of the Bible on a "higher world"49 and gave up the historical factuality of the Bible.

48 Quotations from Harinck, "Twin Sisters," 330.

49 Harinck, “Twin Sisters,” 329. 
Both the modern and ethical theologians were incorrect in their views of the Bible. Over against their positions Kuyper maintained an organic view of inspiration where revelation and history were inseparable and dual authorship of the Bible, divine and human, could be maintained. Kuyper's contention with the modern theology is not with the exegetical (the historical-criticism) method itself. Rather, he objected the modernists' denial of the Bible's divine character which, and in so doing, takes the life out of the Bible. On the other hand, by relativizing history, the ethical theology failed to offer an acceptable solution on the relationship of faith and scholarship. Bavinck also criticized de la Saussaye in the same manner, arguing that under the system of the ethical theology, "there is no longer any (scriptural) authority." 50 In other words, "in all disputes the text of the Gospel does not have the final word." ${ }^{51}$

At this point it is important to note that the framework Kuyper (and Bavinck) used to counter both modern and ethical theologians was also the same framework he would use to counter Darwinism: the organic view of history, a subject we will discuss next.

In his widely-acclaimed Lectures on Calvinism delivered at Princeton in 1898, Kuyper mentioned four positive things that Calvinism had contributed towards science, namely: it fostered love for science; it restored to science its domain; it delivered science from unnatural bonds; and finally, it sought and found a solution for the

\footnotetext{
50 Bavinck, Reformed Dogmatics, 1:462.

51 Harinck, “Twin Sisters," 330.
} 
unavoidable scientific conflict. ${ }^{52}$ For Kuyper it was "Calvinistic dogma of predestination" that gave "the strongest motive . . . for the cultivation of science in a higher sense." 53 Kuyper went on to say that "Faith in such an unity, stability and order of things, personally, as predestination, cosmically, as the counsel of God's decree, could not but awaken as with a loud voice, and vigorously foster love for science" and "without a deep conviction of this unity, this stability and this order, science is unable to go beyond mere conjectures." ${ }^{54}$ In fact, for Kuyper, a Calvinists who seeks God "does not for a moment think of limiting himself to theology and contemplation, leaving the other sciences, as of lower character, in the hands of unbelievers." 55 Believing that there is no conflict between faith and science, how would Kuyper address the most pressing scientific issue of the time, the evolution of species?

In 1899, at the conclusion of the nineteenth century, Abraham Kuyper opened his rectoral address at the Free University of Amsterdam with the declaration that "Our nineteenth century is dying away under the hypnosis of the dogma of evolution." 56 Kuyper's opening statement at the end of the nineteenth century may give an impression that Kuyper was against science and any notion of

\footnotetext{
52 Abraham Kuyper, Lectures on Calvinism (Grand Rapids: Eerdmans, 2009), 110.

53 Ibid., 112.

54 Emphasis is his. Ibid.,115.

55 Kuyper, Lectures, 125.

56 Abraham Kuyper, "Evolution," Calvin Theological Journal 31 (1996): 11. This address was delivered at the transference of the rectorship at the Free University on October 20, 1899.
} 
species evolution in particular. Upon closer examination, however, the contrary is true. There is no doubt in Kuyper's mind that changes in species occurred. Yet, at the same time, Kuyper condemned Darwin's idea that natural selection is the driving force to account for these changes. The key to understand Kuyper here lies in his distinction between facts and the interpretation of those facts. Since everybody possesses beliefs, there is no neutrality; different beliefs cause people to interpret the same facts differently. Maintaining that every science must start from faith-e.g., faith in self, in our selfconsciousness, in the accurate working of our senses, in the correctness of the laws of thoughts; in the principles, from which we proceed-Kuyper argued that the conflict over Darwinism is not between faith and science; in fact, such a conflict does not exist. ${ }^{57}$ Rather, the conflict is between "two scientific systems . . opposed to each other, each having its own faith." 58

Unbelievers and believers were labeled Normalists and Abnormalists, respectively. The Normalists hold that the cosmos "moves by means of an eternal evolution from its potencies to its ideal" and the Abnormalists hold that "a disturbance has taken place in the past, and only in regenerating power can warrant it the final attainment of its goal." Refusing to deal with other than natural data, the Normalists "do not rest until they have found an identical interpretation of all phenomena, and oppose with the utmost vigor

\footnotetext{
57 Ibid., 131.

58 Emphasis is his. Ibid.,115.
} 
[and] reject the very idea of creation, and can only accept evolution." The Abnormalists, however, "do justice to relative evolution but adhere to primordial creation over against an evolution in infinitum." 59 These two worldviews, normal and abnormal, are "two absolutely differing starting-points," and as such they "never intersect." 60 Modern theology, Kuyper asserted, was "the attempt to cleanse theology of its abnormal character in such a thorough manner that Christ was transformed into a man, born as we are born, who was not even entirely free of sin, and the Holy Scriptures into a collection of writings." 61 The Normalists' dogma of evolution attempts to explain the entire cosmos, including all life processes within, to the very earliest origins, by means of its "monistic mechanics." ${ }^{2}$ Through this overarching metaphysics, the dogma of evolution conceives only the natural events and reduces the "spiritual" to a mere chance product of matters. It is precisely at this starting point where the two mutually-exclusive systems of faith, Christianity and "pseudodogma" of evolution, clashes.

Kuyper considered the studies of the Darwinistic school as the studies of well-established facts. Raising the question "If you ask whether we must therefore write off as worthless the studies of the Darwinistic school, most broadly conceived," Kuyper replied by

\footnotetext{
59 Quotations from Kuyper, Lectures, 132.

60 Ibid.,134.

61 Ibid.,135-136.

62 Kuyper, “Evolution," 12.
} 
asking: "permit me to reply by asking whether well-established facts can ever be amortized?" Bluntly he answered: "Nay, rather, all who love the light exult in the wealth of facts revealed by these studies and in the impetus to even deeper, more methodical research that they produced."63 "The dispute, therefore," for Kuyper, "does not involve those facts, but the explanation of those facts." ${ }^{64}$ For Kuyper, the mechanistic production of the living from the nonliving is a delusion and a misunderstanding. ${ }^{65}$

Kuyper's contention is not with the idea of species evolution, but rather the explanation that accounts for that evolution. In fact, Kuyper's organic view of history made room for him to affirmatively and without reservation consider creation and development together. Just as the Scripture is written by two authors, God and human, so it was also imaginable that the world was created by God through natural processes. The organic view of the Bible corresponds to the organic view of history. In this case, the creation of the world involving natural processes would be no less miraculous. Kuyper elaborates:

"We will not force our style upon the Chief Architect of the universe. If $\mathrm{He}$ is to be the Architect, not in name only but in reality, He will also be supreme in the choice of style. Therefore if it had pleased God not to create the species but to have one species emerge from another, through the medium of enabling

\footnotetext{
63 Kuyper, "Evolution," 17.

64 Ibid.,29.

65 Ibid.,48.
} 
a preceding species to produce a higher following species, creation would still be no less miraculous. However, this would never have been the evolution of Darwinism, for the preestablished purpose would then not have been banished but would have been all-controlling, and then the world would not have constructed itself mechanistically, but God would have constructed it by the use of elements that He himself had prepared."66

While Darwinism teaches a mechanistic origin of things, one that excludes design and purpose, based on the facts of biological evolution, Kuyper proposed an organic "evolutionistic creation" theory, one that "presupposes a God who first prepares the plan and then omnipotently executes $\mathrm{it}^{\prime \prime 67}$ in nature. Since unfolding (e.g., of a plan) can only be done by a living organism - since in the strict sense of the word, to 'evolve' is to 'unfold-and since Darwinism "tolerates nothing but mechanistic action, from beginning to end," Kuyper argued that Darwinism did not give a true evolutionary theory; it has been "parading under a false banner."68 Only "evolutionistic creation" maintains the true organic relation between God and nature and, for this reason, it is the only true theory of evolution.

When we come to Bavinck we see a harmony of perspective between him and Kuyper. The concept of evolution itself, argued Bavinck, is not new. Understood as 'development,' or a process of becoming, the idea of evolution already originated in the classical

\footnotetext{
66 Ibid.,47.

67 Ibid., 48.

68 Ibid.,16.
} 
Greek philosophy with Heraclitus, Empedocles, Anaxagoras, Plato, and Aristotle. ${ }^{69}$ Bavinck goes on to say that Christianity took this idea of development and enriched it through, first of all, its doctrine of creation. Christian's doctrine of creation also liberates Christians from the dualistic view of the Greeks philosophy which sees the divine and the physical as co-existing from eternity. Instead, the material world was created. In the doctrine of creation we see that nature was not a dark, demonic mass ${ }^{70}$ but rather it "originated from and through the word and therefore was a part of divine thought."71

The concept of development was replaced by a totally different idea in the nineteenth century, uprooting it from its theistic foundation. While formerly "development was understood generally as an organic, progressive, teleological process, and it was used to posit a logical, idealistic order between creatures," today the word development (evolution) carries new characteristic: a sense of descent, the complex organism from the less complex, spirit from matter, soul from body, thought from brains, life from death, all mechanically and naturalistically and without plan or goal.

In this context, Bavinck declared at the beginning of the twentieth century that "Unless we are mistaken in our interpretation of the signs of the times, the twentieth century, upon which we have

\footnotetext{
69 Bavinck, "Evolution," in Essays, 105-106.

70 Ibid., 107.

71 Clearly Bavinck does not hold to pantheistic view of the world. For Bavinck, "the world did not merely have fellowship with the idea," but rather "it proceeded from the idea." In other words, "the world was the incarnation of thought." See Bavinck, "Evolution," 106-107.
} 
just entered, is to witness a gigantic conflict of spirits."72 This spiritual conflict is a conflict between the old and the new world-view. This new world-view "undertakes to interpret not merely the inanimate but also the animate creations, not merely the unconscious but also the conscious ... independently of God, and only and alone from an immanent self-development." ${ }^{\prime 3}$ Bavinck also described the conflict of two worldviews, "the world-view of development over against that of creation," in antithetical language: a conflict between "the irreligious over against the Christian, the atheistic over against the theistic, the mechanical over against the organic."74 And just like Kuyper before him, Bavinck argued that this new worldview of development is not a product of science, but rather "a play of conceptions," and, thus, "is no science in any serious sense, no science exacte, as it is claimed to be, but a world-view with which the subject plays his part, a philosophy as uncertain as any system of the philosophers."75

Over against the unbelievers' monistic worldview that attempted to find unity of all organisms, living and non-living, "in a cold, dead substance," Christians too acknowledge that there is such a unity, "which holds and binds together all created things," and this unity lies "in the living God ... in his consciousness, in his will, in his counsel."76 In its true sense of the world, "Development stands

\footnotetext{
72 Bavinck, “Creation or Development," 849.

73 Ibid.,850.

74 Ibid., 852.

75 Ibid.,856.

76 Ibid.,859.
} 
between origin and end; under God's providence it leads from the first to the last and unfolds all the riches of being and of life to which God gave existence."77 In just this brief statement, in the similar line of argument, Bavinck argued that the Darwinists, with their mechanical world-interpretations "have unlawfully appropriated" the word 'development.'"78 But provided that evolution is not understood naturalistically, mechanistically, and, thus, atheistically then, Bavinck asserts, "there is ... no antithesis between creation and development."79 And just like Kuyper, Bavinck also believed that the development in species as true, stating

"That evolution exists ... is after all proved throughout the history of peoples and humanity by every organism that comes into being and perishes. There is heredity but also variation, as appears from the difference in children born to the same parents, the races among humans, plant culture, and animal husbandry." 80

Bavinck also allows what we will now call "macro-evolution," that the development of species have occurred across "boundaries of species." Thus, plant and animal developments may increase the multiplicity of species. In Bavinck's own words:

"The extent of this variation is unknown at this point. But it certainly is not limited to the boundaries of the species.... Our understanding of species is unsure and is far from being fixed. It may be changed,

\footnotetext{
77 Ibid.,866.

78 Ibid.

79 Ibid., 117.

80 Ibid.
} 
reduced, or expanded at any moment by scientific research. The species that we accept today in the plan and animal world do not coincide therefore with those that Godby his creative power called into being at the beginning. Most likely the latter [at the beginning] were much fewer in number." 81

And in acknowledging that "God by his creative power called into being at the beginning," Bavinck clearly proposed for "evolutionistic creation," in conformity with Kuyper.

In summary, allowing for development in species over extended period of time, both Kuyper and Bavinck were unlike other fundamentalists of their times. Neither one of these towering figures of Dutch neo-Calvinists oppose to the progress of science. Their contentions with Darwinism was not with the development of species per se, but with the naturalistic, mechanistic, and, thus, atheistic, interpretation behind it. ${ }^{82}$

\section{Darwinism and the later Dutch neo-Calvinists}

It is interesting to note that later generation of neo-Calvinists were quite skeptics, if not downright dismissive, towards any form of evolution theory. Notwithstanding his great authority and rhetorical skills, Kuyper "was not very successful in persuading his co-

\footnotetext{
81 Ibid., 117.

82 It is worth pointing out that there was a harmony of perspectives between these Dutch theologians and their counterparts across the Atlantic, the Princeton theologians. See David Tong, "The Relationship between Christianity and Science: A Brief Historical Study on Darwinism and the Old Princeton Theologians," to be published in Societas Dei 1, no. 1 (Oktober 2014)
} 
religionists to revise their position." 83 Hendrik van der VaartSmit, for example, argued, to the contrary of the position of his teacher Bavinck, that life has been the same from the beginning. ${ }^{84}$ Valentine Hepp (1879 - 1950), Bavinck's successor at the Free University, provides further proof of second generation Dutch neo-Calvinist resistance towards evolutionary theory. While acknowledging in the one hand that the Scripture "does not contain data of nature," that these data "are to be found outside of the Scripture in nature itself," and that the Scripture "does not give . . . any results of natural research, and certainly does not build any theories or hypotheses," ${ }^{85} \mathrm{Hepp}$, regardless, went on to say that

"Today we have arrived at the view that Scripture is silent concerning the absolute age of the earth, and even concerning the absolute age of man. The indications of Scripture are so clear, however, that the Christian who reveres it, cannot and may not take part in the paleontological and geological hunt after millions. The Scripture excludes the possibility of the human race being two hundred thousand years old. And that organic life came into being millions of years ago must be judged a myth. It is not true that the data of the natural sciences demand such high number; the evolutionistic principle demands this. It is the antithesis against faith in creation that drives to these excesses. This movement is called into being by the desire to depose the Creator of the universe and the Former of the earth willingly or unwillingly. Should not all Christians from all lands unite to oppose this? . . . They should have, certainly! But it did not

\footnotetext{
83 Visser, “Dutch Calvinists," 295.

84 Ibid.,298.

85 "Valentine Hepp, Calvinism and the Philosophy of Nature (Grand Rapids, MI: Eerdmans, 1930), 87."
} 
happen." 86

Kuyper and Bavinck both accepted the facts of evolution while denying the mechanistic and naturalistic interpretation of it. But, clear from the quotation above, no consideration of evolution is given by Hepp. In practically overnight, attitude towards evolution has shifted. And it seems all "transition forms" that may explain the evolution of thoughts from Bavinck to Hepp seem missing. "The promising start made by Kuyper and Bavinck in renewing theological thinking was eclipsed by their successor' need to safeguard theology from all kinds of liberalizing influences, science included." ${ }^{87}$ On this sudden shift of attitude, Visser writes:

"While Kuyper and Bavinck created a hermeneutical space to accommodate certain elements of Darwinism, their successors did not make use of it for that purpose. After Kuyper and Bavinck, opposition to every aspect of the theory of evolution once again became standard among neo-Calvinist theologians. If the second generation ever spoke publicly about evolution at all, it was to resist it and, occasionally to declare it out of bounds for true believers. These reactions often had a hard-line character, offering no prospect to compromise. . . . The second generation of neo-Calvinist theologians did not show any inclination to integrate their exegesis with the results of evolutionary biology." 88

Two questions can be asked. First, "What happened?" My limited research, within the available English translations only, unfortunately,

\footnotetext{
86 Emphasis is his. This comment, for me, implies that Hepp, unlike Kuyper and Bavinck before him, rejected any consideration of evolution whatsoever. Ibid.,200-201.

87 Visser, “Dutch Calvinists,” 312.

88 Ibid.,297-298.
} 
does not yield definitive answer. Some plausible explanations can be offered.

1) The eclipse of Darwinism towards the end of the nineteenth and well into the few decades of the twentieth century could have played a factor. The rise of neoDarwinism did not come until the 1940s-1950s. Other competing evolutionary theories existed and precisely because of the many varieties of these evolutionary theories, all of these theories may be seen less scientific. In addition, competing theories over the age of the earth may add to the confusion. Surveying the many different methods used to estimate the age of the earth, with each yielding answers conflicting one another, Hepp seemed to argue that all of these works were simply "guesses" and "speculations" rather than a solid scientific fact. ${ }^{89}$

2) The rise of Flood Geology (also known as "Creation Geology" or "Dilluvial Geology") developed by creationist and seventh-day Adventists George McReady Price in 1923 was seen by many Christians as advancing their literalist reading of Genesis 1 as both biblical and scientific. In his 1930 Stone Lecture at Princeton, Hepp did mention Price's Flood Geology and seemed to consider it scientific, despite

89 Hepp, Calvinism, 193-197. 
the fact that he acknowledged that Price's authority on the subject has been severely questioned..$^{90}$

3) War changed people. At the time Kuyper and Bavinck developed their view of evolution, the French Revolution of the 1790s was already a distance past and World War I was still decades in the future. When the First World War broke in 1914, Kuyper and Bavinck were already late in their respective lives and their view on many subjects matured already. On the other hand, Hepp was quite young at 35 years old when the war came. The same holds true to many of the second generation of Dutch neoCalvinists. Hepp himself would live to see the Second World War. Many have seen the "progress" advocated by evolution theory and the modernist liberals to be nothing but hopeful myth given all the terrors, horrors, and aftermaths of both of these wars. War may indeed tip the balance of one's view towards evolution.

The second question, "Is this change of attitude for the better?" Answering this question is not trivial. If we agree with Kuyper and Bavinck, that evolution of species, even across the boundaries of species, is a well-established fact, then I believe Hepp's antipathy against evolution and his denial to even consider the factual data of evolution, is unfortunate. On this question, let me quote what

90 Ibid., 185-186. 
Bavinck had to say: “The relationship between faith and science will certainly improve when the latter surrenders the mechanical worldview; when the hostility toward religion, specifically the Christian religion, is laid aside; and when the other side acknowledges, more so than heretofore, the important element of truth that undoubtedly is implied in the theory of evolution of descent." 91

\section{Conclusion}

At the core, the issue over Darwinism in nineteenth century Netherlands was not the issue of faith vs. science. One's acceptance, or rejection, of Darwinism was primarily determined by one's own religious alignment. This is true for the natural scientists as well as for the theologians. Surveying the responses towards Darwinism among the nineteenth century Dutch natural scientists, for example, we find that, as expected, scientists who were philosophically aligned towards positivism and naturalism (e.g., Pieter Harting and FranciscusCornelisDonders) readily accepted Darwinism, whereas Calvinist natural scientists (e.g., LeendertBouman and Frederik Buytendijk) showed some resiliency. When theologians were surveyed, the same conclusion holds true. The modernists, without doubt, had no reservation embracing Darwinism for in it they find support for their own progressive theology. Attitude towards Darwinism among the nineteenth century Dutch Calvinist

91 Bavinck, “Evolution," 117. 
theologians, however, varies widely, from complete rejection of any theory of evolution to some forms of accommodation.

Rejecting Darwinism, however, does not imply hostility towards the progress of science or, for that matter, necessitates a denial of species development. Both Abraham Kuyper and Herman Bavinck, the two towering figures of the Dutch neo-Calvinist movement, were receptive to the idea of species developments yet they rejected the mechanistic, naturalistic, and, thus, atheistic explanation to these development as offered by Darwinism. When it comes to the issue over Darwinism, Kuyper and Bavinck rejected that the conflict is between faith and science. The real conflict is a conflict between two diametrically opposing and antithetical system of beliefs, each giving their own interpretations over the same factual data of nature. This allows them to accept the facts of evolution (that species do change over time) as well-established facts, while denying the mechanistic and naturalistic interpretation of these facts (e.g., Darwinism). Arguing that the mechanistic view of evolution such as Darwinism is not a true evolution theory, both Kuyper and Bavinck proposed a true view of history, the theory of "evolutionistic creation," in which they acknowledged both the activity of God in creation by and through the process of development. Even if living organisms have evolved, even across the boundaries of species, "creation would still be no less miraculous." Bavinck went on to say that the relationship between faith and science will improve if the latter gives up its mechanistic view and the former accepts that there 
exist element of truth in the theory of evolution.

It is interesting to note, however, that Kuyper's and Bavinck's views were not embraced by the later generation of Dutch Calvinists. Valentine Hepp, Bavinck's successor at Free University, for example, rejected any consideration of evolutionary theory. Some reasons have been proposed to explain this sudden shift of attitude: the eclipse of Darwinism at the end of the nineteenth century and into the early decades of the twentieth, the rise of Price's Flood Geology, and the effect of the World Wars in the twentieth century. More extensive research is in order to provide a more comprehensive and definitive picture. 